the address showed clearly that, when a therapeutic substance has been discovered or synthesized, a great deal more remains to be done before it can be released for use. It is necessary to make sure that its pharmacological and therapeutic activities do not vary from batch to batch of the manufactured product. The biological activity of drugs which eannot, for various reasons, be made in a chemically pure state must be controlled by biological tests on animals; and carefully planned and rigidly controlled clinical trials on human patients are done whenever these are possible. Nor must we forget the considerable work required to ensure that the drug is issued in a form in which it shows its characteristic properties, that it is safe and convenient to use and that it remains stable for a reasonable time under the climatic conditions to which it is to be subjected. "This task, known as the formulation of medical substances, is the responsibility of the pharmacist.

Discussing the international aspects of drugproduction, Dr. Boyes commented on the growing need for close international collaboration between the pharmacists of all nations and indicated the progress made in this respect. The publication by the World Health Organization of an International Pharmacopoia should help to extend international agreement on standards for drugs and pharmaceutical preparations.

In conclusion, Dr. Boyes discussed the responsibilities of the pharmacist and claimed that modern pharmacy should be, not the handmaid of medicine, but its co-partner with equal responsibilities. His address will evoke much sympathy with this view. Some readers of it will wonder, however, why it does not consider the needs and work of the modern veterinarian, who is, to an ever-increasing degree, collaborating with, and making important contributions to, human medicine. A future which gave us the medical man, the veterinary surgeon and the pharmacist as equal partners in a humanitarian team would indeed be worth living to see. There is much evidence that it will, in fact, be the heritage of a generation not very far removed from the one to which Dr. Boyes belongs.

G. LAPAGE

\section{A NEW FOSSIL MAN FROM SOUTH AFRICA}

\section{By DR. J. C. TREVOR}

Department of Archæology and Anthropology, University of Cambridge

$\mathrm{I}^{\mathrm{N}}$

N January 1953, Mr. Keith Jolly, an archæologist, 1 recovered the major portion of a human calotte from the surface of a wind-eroded site about midway between the village of Hopefield in the Cape Province and the southernmost extension of Saldanha Bay. Only brief preliminary accounts of the Hopefield site and 'Saldanha Man' by A. J. H. Goodwin (S. Afric. Archool. Bull., No. 30, 41, Claremont, Cape Town; 5s.) and Prof. M. R. Drennan (S. Afric. J. Sci., 50, 7 (1953); Illust. Lond. News, No. 5971, 480 (Sept. 26, 1953), 2s.) have so far appeared, and even since these were written additional information relating to the discovery has become available. Curiously enough, C. P. Thunberg (1743-1828), who was to succeed Linnæus at Uppsala in 1784, had in his thirtieth year visited the farm Elands- fontein, on which most of the site lies, and he later described its flora and fauna. The fossiliferous nature of the Elandsfontein deposits, however, did not become apparent until shortly after the Second World War, and credit for ensuring that their possibilities were not neglected must be given to a small committee formed under the chairmanship of Prof. Drennan at the University of Cape Town.

A rare giraffid (Griquatherium) occurs among the fossil mammals, of which the extinct forms are represented most abundantly by the Cape horse and the living forms by several genera of the commoner African antelopes. The fluorine content of the remains of a selected series of the extinct animals, including the giant wart-hog Mesochoerus, and that of the human skull-vault, were recently determined in London by C. F. M. Fryd, of the Government Chemist's Department, and there is a remarkable agreement between them. Because of the high rate of fluorination at the site, Dr. K. P. Oakley, of the British Museum (Natural History), who recently inspected it, considers that their geological ages are, within narrow limits, identical. On the basis of faunal and archæological correlations elsewhere in the Union, he also tentatively supposes that the man of Hopefield should be associated with the Late Acheulean or Fauresmith hand-axes, characteristic of the South African Earlier Stone Age, rather than with the Still Bay points, which typify the Middle Stone Age. Artefacts belonging to both cultures are found on the site; but those of the Still Bay indicate only its earlier or typical phases. No trace of the use of fire has yet been observed.

The human bones, which are being studied by Prof. Drennan, comprise the frontal, both parietals, and the occipital of a young adult subject whose probable sex is regarded as male. Their owner was manifestly different from any normal member of the species Homo sapiens, and what is preserved of him bears a strong resemblance to the cranium from the Broken Hill Mine in Northern Rhodesia, accidentally brought to light on June 17, 1921, and now at South Kensington. The most detailed examination of the Rhodesian skull is that made by Dr. G. M. Morant (Ann. Eugen., 3, 337; 1928), who concluded that, although more closely related to certain Neandertaloid types than to modern man, it could be clearly distinguished from both. A striking feature shared by the Hopefield and Broken Hill specimens is the lateral massiveness of the torus, or bony bar, above the orbits-not so pronounced in the Hopefield calotte, of which almost the entire missing left browridge has lately been retrieved-but Prof. Drennan is also impressed with the apparent affinities of the new African find to the far-removed ancient Ngandong hominids of central Java. The results of his investigation will be eagerly awaited in view of the importance they are bound to have for the advancement of knowledge in the field of human palæontology.

\section{O BITUARIES}

Sir Thomas Taylor, C.B.E.

Trre sudden death on August 29 of Sir Thomas Taylor will be mourned by members of universities and allied bodies throughout the world. Widely known, loved and respected, his untimely death at the age of fifty-eight will come as a cruel blow. 
Fellow and former Scholar of Brasenose College and a Rhodes Travelling Fellow, he taught and made distinguished contributions to chemistry, notably stereochemistry. His name is connected with two standard works, the English revision of "Richter", the second volume of which he edited, and Sidgwick's "Organic Chemistry of Nitrogen", which he revised in conjunction with Prof. Wilson Baker.

He served with distinction in the two World Wars, and in the second played a major part in the organization of the British Commonwealth Scientific Office in Washington, as well as serving as scientific advişer to the Supreme Allied Commander, SouthEast Asia. Afterwards, he became principal of the University College of the West Indies, in Jamaica, and in 1952, of the University College of the SouthWest, Exeter. It is fitting that his services were recognized by the award of the C.B.E., and later, of a knighthood.

A mere catalogue of Sir Thomas Taylor's distinguished career and singular range of achievements, however, would form an inadequate tribute, for he was a man of many parts, an impressive scholar, gifted with an acute and agile mind, which, coupled with vision and prodigious energy, marked him as an outstanding university administrator. He was a man of paradoxes as well as of parts. A vivid personality, yet modest; disconcertingly direct, yet kind; a man with clear-cut likes and dislikes, yet deploring alike fulsome praise and harsh criticism. $\mathrm{He}$ was a scholar with a zest for living and had a rich human understanding, with a pervasive sense of humour. Cultured, widely travelled, with a rich store of anecdote, aided by a remarkable memory, to receive his hospitality, and to listen to his witty, wellinformed conversation, was an engaging and stimulating experience.

Of his many achievements, both in his beloved Oxford and elsewhere, none can be judged greater than his leading part in the creation of the University College of the West Indies, in the form envisaged in the Irvine Report. His discharge of the duties of first principal was masterly, and won for him universal respect and admiration. All who served with him have reason to remember his wisdom, guidance and example with enduring gratitude. He faced unflinchingly the unending succession of stern tasks inevitable in the creation of a new institution of this character, and owing to his unfailing wisdom, leadership and immense drive, they were accomplished. When, in 1951, all seemed to have gone so well, the young and growing college was seared by a devastating hurricane at a most critical time. It was his courage, determination and buoyancy of spirit that did so much to allay discouragement and to re-invigorate all efforts. Despite the pressure and burden of administration, he spared no pains to come to know every member of his staff and all undergraduates, and his sympathetic guidance was always freely given.

The universities and colleges Sir William served were not alone in receiving the benefits of his scholarly gifts and administrative experience, for they were given unstintingly in the wider sphere of higher education within the British Commonwealth, and societies fostering cultural activities in many forms received his valued support, together with that of Lady Taylor. Musicians, naturalists and bird lovers with unbounded enthusiasm, their combined activities have enriched the annals of such organizations in many parts of the world.
His passing will be deeply felt by friends scattered throughout the world. To Lady Taylor, who survives him, we offer our deepest sympathy.

NoRMan MiLLotT

\section{Prof. E. C. Jeffrey}

Edward Charles Jefrrey, professor of plant morphology at Harvard University, died on April 19, 1952, in his eighty-sixth year. A Canadian by birth, and a graduate of the University of Toronto, he received a doctorate from Harvard University in 1898, and in 1902 was made a member of its Faculty. His position in the field of botanical research is attested by a list of 115 publications, and his success as a teacher is evidenced by some thirty graduate students trained under his direction and well represented among active American botanists.

Prof. Jeffrey was one of that small band of British post-Darwinian plant morphologists including Scott, Bower, Worsdell and Gwynn-Vaughan which, at the beginning of the century, set itself to reconstruct the evolutionary history of vascular plants. At the very outset of his studies, Jeffrey took up the stelar theory of van Tieghem and established it on a sound foundation. Then he began a search for valid evolutionary criteria applicable to the vegetative parts of vascular plants. $\mathrm{He}$ utilized the current biological doctrines of retention, reversion and recapitulation in an attempt to relegate them to their proper phyletic positions and, above all, he explored the fossil record, which he realized was the final court of appeal in evolutionary problems. He was a pioneer in the work on Mesozoic lignites and, incidentally, he brought the celloidin technique to a point of high precision. From the lignites it was but a step to the study of the microscopy of coal, a subject to which he devoted enormous labour. He advanced a sound anatomical interpretation and ecological explanation for the evolution of angiosperm herbs from woody ancestors. In his later years, he turned to cytogenetics and was a pioneer in the assertion that "the angiosperms are a mass of hybrids", and that an evolutionary theory based upon the cavortings of Oenothera lamarckiana was indeed a "mutation myth".

Prof. Jeffrey was a creative genius and a man of strong enthusiasms and convictions. Almost of necessity he became a controversial figure in American botany. He was a Darwinian who lived to see the superb confidence of his predecessors called in question, and their positive ideals supplanted by a mechanistic and negative outlook. Many of his conclusions ran counter to long-established views, and he met the common fate of the iconoclast. The criticisms levelled against him were often unfair and were based upon superficial understanding and wounded vanity. A policy of studied neglect was effectively applied to his work and others reaped where he had sown.

But the tide is turning, and some leading American workers are already aware of the fact that later discoveries have supported Jeffrey's views surprisingly. It is a safe prediction that the future will set his name high on the roll of those who have made permanent contributions to the philosophy of botany. Then the words of his own sturdy faith, so often repeated, will be amply justified : "Good work tells in the end".
RAY E. TORREY 